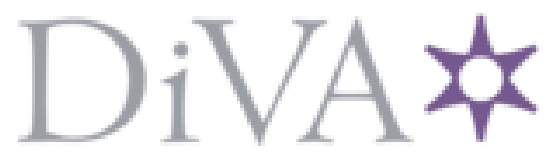

http://www.diva-portal.org

This is the published version of a paper presented at ESIL 2013, 5th Research Forum: International Law as a Profession Conference, Amsterdam, The Netherlands, 22 - 24 May 2013.

Citation for the original published paper:

Wrange, P. (2013)

The Limitations of International Law Expertise - War Amongst Peacemakers: The Juba Peace

Process as Battleground for International Lawyer's Biases.

In: Nico Krisch, Mario Prost, Anne van Aaken (ed.), Europen Society of International Law:

Conference Paper Series

ESIL Conference Paper Series

https://doi.org/10.2139/ssrn.2364070

N.B. When citing this work, cite the original published paper.

Permanent link to this version:

http://urn.kb.se/resolve?urn=urn:nbn:se:su:diva-98002 


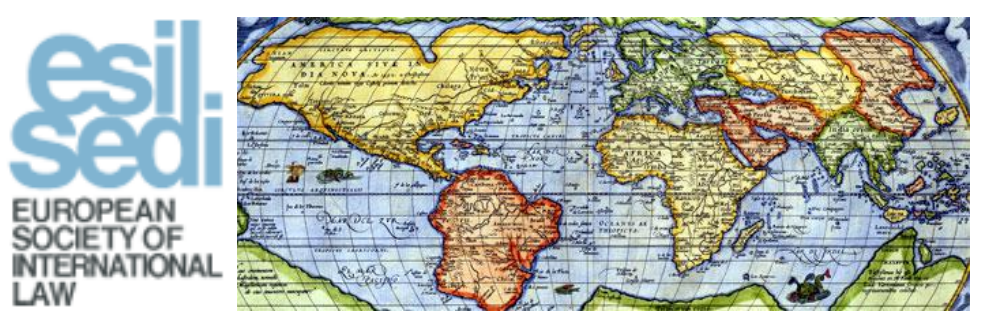

\section{EUROPEAN SOCIETY OF INTERNATIONAL LAW}

Conference Paper Series

Conference Paper No. 6/2013

Amsterdam Research Forum, 23-25 May 2013

The Limitations of International Law

Expertise - War amongst Peacemakers:

The Juba Peace Process as Battleground for International Lawyer's Biases

Pål Wrange

\section{Editors:}

Nico Krisch (Institut Barcelona d'Estudis Internacionals)

Mario Prost (Keele University)

Anne van Aaken (University of St. Gallen) 


\title{
THE LIMITATIONS OF INTERNATIONAL LAW EXPERTISE - War amongst the Peacemakers: The Juba Peace Process as Battleground for INTERNATIONAL LAWYERS' BIAS
}

\author{
Pål Wrange
}

\begin{abstract}
:
This paper reflects on the limitations of international law expertise, using examples from the Juba peace process on the civil war in Uganda. In peace negotiations (like in all situations), the international law expert must acknowledge the limitations of international law. International law is one-dimensional, and cannot take all relevant factors into account. Further, in any given situation, there will be some regimes and some rules of international law that are more effective than others, because they have powerful support or efficient mechanisms. This means that some norms, some claims and the interests of some stakeholders will be privileged. Many of the controversies associated with international interventions based on international law - like the ICC prosecutions in Uganda - have in fact been caused by too much emphasis on, for instance, international criminal justice and civil rights, and too little emphasis on reparations, economic and social rights and collective rights. Still, even if international law could be better used, there are limits to what can be accomplished even with creative international law expertise. There is a structural bias in international law, which privileges the state. International law, and its institutions, can do too little to refer matters from the government to other legitimate stakeholders, often leaving us with a choice between the (distant) supranational level and the (corrupt) national level. While international law does determine an international minimum standard for the state, it is still much better at empowering the government than at empowering people.
\end{abstract}

Kewords: ICC; Juba; Uganda; international law; legal expertise

\section{Author Information:}

Professor of International Law, Stockholm University, Director, the Stockholm Center for International Law and Justice, pal.wrange@ juridicum.su.se 


\section{Table of Contents}

1. Introduction

2. The Context of International Law Expertise.

3. Limitations of International Law Expertise ..............................................6

4. Intervention, Reflection

\section{Introduction}

In a damning indictment of international law, and in particular of "interventionist human rights discourse", anthropologist Adam Branch claims that interventions by international human rights NGOs, the International Criminal Court and Western governments contributed to prolong the twenty year civil war in Uganda and even enabled the displacement of the civilian population. ${ }^{1} \mathrm{I}$ spent three years in Uganda, possibly adding to this mess.

It is not hard to find a retort to allegations of intervention: 1) there is nothing neutral or given about the situation before an intervention and it is not the case that there is no hierarchy, no oppression and no deprivation where the international expert does not intervene; 2) there are no hard boundaries between the North and the South, or between what is inside Uganda and what is from the outside; 3 ) no matter what you do (and inaction can also be a form of action), there will be unintended consequences (and that applies to anthropologists, too).

Nevertheless, there is a hard and important kernel of truth in what Branch says. In this presentation I will put myself as an international law expert on the couch, as it were, and discuss the limits of international law expertise, with examples from the peace process in Uganda. This process made me change some of my views on international law, and made me humbled by the complexities of the situation, and by the amount of available and relevant knowledge that was not possible to assess with my technical expertise.

The Juba Peace Process between the Government of Uganda and the Lord's Resistance Army (LRA) rebel group took place in the shadow of on-going ICC prosecutions against the leaders of one of the parties (the LRA). The peace talks therefore had to navigate in a context in which some previously open avenues - such as comprehensive amnesty - had been closed by the indictments. Hence, there was a great need for international law expertise during the negotiations, which resulted in an impressive array of transitional justice provisions - dealing with the ICC, national prosecutions, truth-telling, reconciliation and traditional justice.

International law expertise was also needed in the (fledgling) implementation. The Agreement on Accountability and Reconciliation (A\&R) of 2007 required that the Government take a number of measures to implement it, by preparing for investigations, prosecutions, trials, reparations and alternative justice mechanisms (truth and reconciliation, traditional justice). These tasks, which were given to an inter-agency Transitional Justice Working Group, were not only politically charged, but also technically quite complex and far from the usual activities of lawmakers.

\footnotetext{
${ }^{1}$ Adam Branch, Displacing Human Rights: War and Intervention in Northern Uganda, OUP 2011, p 4.
} 
I followed the peace process in different capacities between 2004 and 2010: first as a legal advisor at the Swedish Ministry for Foreign Affairs, then as a consultant to the Swedish Embassy in Kampala and to other embassies, as a consultant to various NGOs and, lastly, as a political advisor to the European Union. I assessed the compatibility of the peace process with the Rome Statute of the ICC, I sought ways of stopping the war, and I tried to promote and influence the implementation of the transitional justice provisions of the agreements. In these different capacities, I met a wide range of interlocutors and interacted with them in different ways and with different purposes - most closely with the actors that were involved in the implementation of the A\&R Agreement.

What I will offer here are my reflections as an external, but still a "participant observer", and these reflections will cover both my own role and the limitations of international law expertise in peace processes. The findings/judgments, or views, presented in the paper relate to the function and the functioning of international law - which essentially are questions of social sciences. They are, however, not based on empirical investigations ${ }^{2}$ - for which I have no skills - but rather on personal experience. Of the many processes that I have been involved in as a lawyer, it was in the Juba Peace Process that I had my most sustained engagement, and arguably the one where the relation to the social reality ultimately affected by international law was the closest. I will therefore use this experience as a repository of examples for the paper (as well as for two related book projects ${ }^{3}$ ). Strictly speaking, Juba was a part of the context of discovery of my findings, but for the reader, of course, my references can at best provide anecdotal or suggestive support for my ideas. While some of the views presented here can be tested against broader research, I think that some of them can only be accepted or refuted on the basis of the logic of the argument and on what the reader already knows or has experienced.

In the course of my work, I did not experience any great difficulties in connecting to people, and in particular, not with other professionals. Perhaps my interlocutors felt otherwise, but I sensed a collegiality with the other lawyers, including domestic lawyers - that we were parts of the same epistemic community, or even fraternity. Having read a bit on international relations and on conflict resolution, and with ten years of experience as a diplomat, I also felt it was quite easy to connect with other professionals, like peacemakers. We all had a cosmopolitan training - either in Western universities, or in Uganda by teachers who were a part of cosmopolitan epistemic communities. We played different roles, but participated in the same problem-solving activity although we did not always have the same view of what the problem was. When I talked to laymen - victims, rebels, and the army - the common ground of concepts and canons was smaller, but we still shared common human experiences.

Nevertheless, I often felt that there were many things that I did not understand. Even when I was at ease exchanging messages with my interlocutors, I knew that there were political, social, cultural and other aspects which were beneath the discourse, unattainable to me. There were also considerable existential differences; for those involved, the stakes were quite high, while I could leave at any time. And, of course, I could only guess what the colour of my skin meant - surely

\footnotetext{
${ }^{2}$ To my knowledge, very little anthropological work has been produced on the role of lawyers within such contexts.

${ }^{3}$ See footnote 1 .
} 
significant, but different things to different people. I sometimes envied local colleagues who appeared to have deep access to more than one world.

I am born and bred in Western bourgeois culture. If I did not fully grasp what was happening, perhaps international law - which to a large extent comes from that very same culture -- could not fully cover it.

\section{The Context of International Law Expertise}

The most obvious asset of an international law expert is her expertise in international law, and it is international law which provides the legitimacy for the expert's intervention. The expert will be of use only if international law has rules and institutions that are helpful in the case at hand. However, international law is never applied in a vacuum, and it is not neutral.

Firstly, international law is set in a context of legal pluralism with many legal orders as well as different conceptions of justice (criminal justice, reconciliation and integration, social justice, etc.). Its implementation in domestic law is subject to domestic constitutional and other norms; there are national and transnational private norms, and in many countries much of everyday life is regulated by traditional, tribal law; there may be regional or sub-regional norms; and, of course, there may be conflicting applicable norms from different international law regimes (and traditions). Such plurality was displayed in the Juba peace agreements (JPAs). The A\&R Agreements were clearly premised on international criminal law and on international human rights law, they built on existing Ugandan criminal and constitutional law, and they invoked traditional norms. The conceptions of justice involved were different conceptions of justice related to accountability.

The more political Comprehensive Solutions Agreement proceeded from the Constitution and existing regular laws as well as government plans, and it invoked international norms only in very general terms. The conception of justice involved was clearly some form of distributive justice, even though commutative justice or accountability could have been invoked, since the marginalisation that the agreement was supposed to address was at least partly caused by wrongdoings by the government and others (for instance, cattle rustling). The Agreement built almost entirely on the Constitution, and other existing laws and government plans, such as the Peace, Reconstruction and Development Plan (PRDP). While this may appear to add little to what was already in place, the agreement could have strengthened existing, but inefficient, procedures, such as the local consultations on the PRDP. However, it did not, and the implementation of the agreement lay completely in the hands of the government.

Hence, there was a range of relevant norms and normative systems, making it difficult to determine both what "the law" actually said, and how one could expect that law to be implemented. Consequently, in order to provide good advice, the international law expert had to understand international law in an environment of legal pluralism, and textbook terms like monism and dualism had only limited relevance.

Secondly, another factor that the expert needs to take into account is that the effect of international law depends upon those who use it. The actors involved in the Juba Peace Process had various attitudes to international law. While no one explicitly denied the validity of the 
obligations under the Rome Statute, quite a few contested the application of these norms in northern Uganda, and some associated international law with "western justice" and colonialism. Other people were convinced that international obligations had to be fulfilled, either because they were binding or because donor demanded it, while others invoked international law strategically or appealed to international norms as a recourse against injustices.

During the deliberations at the implementation stage the term "international standards" was used regularly. Even though there was a general willingness to comply with these standards, in some cases, there was a feeling that Ugandan standards were good enough, or even superior. For instance, both during the war and during the peace talks, there were many who opposed the use of criminal justice procedures against the LRA. In particular, some sections of civil society advocated for various reconciliation procedures, arguing that African (or local "tribal" Acholi) notions of forgiveness were superior to allegedly retributive Western ideas of criminal law, or at least that the local notions were more appropriate in the particular local context. Among the civil servants involved in the implementation, by contrast, there was a general consensus that domestic prosecutions should take place. That was, of course, because that was already a done deal, in Juba, but that in its turn was called for by the Rome Statute, and it was also provided for by Ugandan law. And there was surely an element of strategizing in this exchange of views. To keep the process in local, Acholi hands would also have meant local control, which can be good or bad, depending who is in control. For the government, the fact that amnesties and non-legal procedures were off the table after the ICC indictments, meant that the room of manoeuvre had shrunk considerably, as I will explain below.

And this brings me to the third factor. International law tends to privilege and support certain stakeholders, for good and for bad. While classical international law is applied only in the context of states, in an internal peace process, such as the one in Uganda, there are many stakeholders involved with different actual or potential claims, invoking different norms in different norm systems: In the present case there were, for instance, the LRA, the civilian victims, the LRA's "own" Acholi tribe, other affected tribes in and out of Uganda, regional powers including (the Sudan) which supported the LRA, the international community, etc., but only some of these were present when the decisions were made. Sometimes the lack of access to the negotiations could be compensated through access to international law, and sometimes international law reinforced the imbalance.

Peace negotiations are intended to end armed conflicts, and in order to have a seat at the table, one needs to have a gun. In Juba, various organisations and groups were present as observers, but in the end it was the two parties that made the decisions, one of which was a small rebel movement with limited local support and the other one was an authoritarian but democratically elected government. Instead of power sharing and devolution, the agreements by and large built on the existing constitution, and the most concrete provisions were on disarmament, demobilisation and reintegration (DDR) and on transitional justice for non-state actors, i.e., they focused on the fate of the rebels.

During the implementation phase, a great number of actors were consulted, including the affected communities and foreign governments. However, the focus was on inter-agency consultations in 
the Ugandan government. Consequently, while a number of stakeholders and interested parties were able to intervene, it was the government which determined the extent of their involvement.

Just as different actors had different access to the negotiations, they also had different access to international law. And an invocation of international law could change meaning over time. The Government clearly used international law strategically, by inviting the ICC under the expectation that that intervention would work to its advantage. That calculation was correct at first, because the ICC indictments did put pressure on the LRA and thus weakened it. At the same time, the Government lost flexibility in the peace talks, since amnesty was no longer an option. While many - but far from all - of the victims had been sceptical of the ICC intervention, some members or advocates of the victim communities discovered over time that international law had a useful repository of arguments which could be used on their behalf; international law provides, admittedly a bit vaguely, for reparations for victims as well as for the participation of victims in criminal processes.

\section{Limitations of International Law Expertise}

So, the effect of international law advice depends upon the context - like the legal context, the attitudes of the actors involved and their access to the process and to international law. But there are also aspects of international law itself -- as a set of norms -- that are problematic, and call for modesty in the part of the international law expert.

We are used to thinking of (and excusing) the weaknesses of international law in a world of power politics. However, paradoxically, in some situations, international law may become problematic, and dangerous, if it becomes too efficient, because it is one-dimensional, and cannot take all relevant factors into account. This one-dimensional quality of international law (as of any legal system) is generally a virtue, because it is only by delimiting its scope of reference that it can produce Rechtssicherheit (legal certainty). (After all, one cannot device rules that take all life's infinitely complexity into account.) However, in complex situations with much at stake such as a peace process - the vices of one-dimensionality often outweigh the virtues of (relative) certainty. The problem is the limited capacity of the international lawyer, qua lawyer, to take all aspects of the situation into account. And only some stakeholders and only some claims are supported by international law.

Over time, I came to understand that to be an expert means to also acknowledge the limits of one's expertise -- to listen to conflict resolution and mediation professionals (as well as encourage them to listen to you), to engage with the development experts and, most importantly, to listen to, be informed by, and sometimes deliberate with, local community leaders, administrators, human rights activists and ordinary people.

Legally speaking, the ICC intervention seemed fairly clear: States parties to the Rome Statute have accepted that it is for the Court to decide, under the principle of complementarity, whether the ICC can prosecute, and these states have accepted the obligation to implement the Court's orders. Hence, the easy option would be to argue for the unconditional execution of the arrest warrants against Joseph Kony and the other LRA leaders. Nevertheless, that was not necessarily the best course of action. Would it not be reasonable to support a peace process that ultimately 
could result in a "circumvention" of the ICC's jurisdiction, if that could stop a cruel war? Was it not legitimate for Acholi leaders to demand that the conflict between their community and LRA leader Joseph Kony be dealt with by them rather than by a court in The Hague? Why was Joseph Kony prosecuted but not those who were responsible for the Government's internal displacement programme, euphemistically called "protected villages"? And should responsibility for atrocities be limited to the direct perpetrators, or should those who wittingly or unwittingly supported the warlords also be held accountable? And, furthermore, could the transition about which everyone spoke not be widened to also encompass the economic and political reforms that so many Ugandans were looking for? For those questions, one must go beyond the provisions of the Rome Statute of the ICC and think about the legitimacy and wisdom of different courses of actions.

But one could often utilise international law arguments, provided that one bother to search. I came to realise that many of the problems associated with the international law intervention in Uganda were contingent on how international law had been used, and that international law's potential was far from exhausted. Even if it had been the ICC prosecutions that put not only the LRA conflict but also international criminal law in the limelight, international law could have much more to say than to just proscribe impunity and provide fair trial rights for those concerned.

Some regimes and some rules of international law are more effective than others, because some are supported by efficient mechanisms or by powerful states and institutions. ${ }^{4}$ In the fields of human rights and international humanitarian law, an ICC intervention has, comparatively speaking, become a strong force for the enforcement of norms on the basic protection of civilians, and such norms are also being promoted by many governments, international organisations and influential NGOs. This is all good, but it means that in many situations there is more focus on these norms than on other norms, and there is more focus on some claims and on the interests of some stakeholders than on those of others.

In the JPAs - like in many other peace treaties -- the main transitional justice items were addressed, and in particular, accountability for violations of international humanitarian law and human rights (narrowly conceived). However, other claims were not addressed at all or only vaguely, and issues of social justice - which could have been dealt with partly as violations of economic and social rights - were not treated as human rights issues, but as problems created by the conflict and by "history".

I believe that the international lawyer should not necessarily accept such contingent biases in international legal discourse, but try to take a more holistic approach (while acknowledging the limitations in her ability to assess that whole). International law has a repository of concepts and notions that could be used. For instance, human rights - vague and contestable as they are - may be a useful way of talking about the balance between the rights and interests of different individuals and collectives. The point is not to provide a blueprint for a future juridico-political order but to help reframe the parameters of the discussion. Human rights is a generally accepted mode of talking about sensitive matters and the concept is wide enough to cover most relevant claims. And, perhaps most importantly, human rights are malleable but not indefinitely so.

${ }^{4}$ The imbalanced relation between international trade law - with its strong WTO dispute settlement mechanism - and international environmental is a well-known example. 
"Justice", as in "transitional justice", should cover not only violations of international humanitarian law and of the civil rights to personal integrity but also violations of rights to political participation as well as violations of economic, social and cultural rights, and also violations of different group rights. Further, the focus of transitional justice should not only include accountability for past events, but also the securing of rights in the future. While it is a stock argument of TJ proponents that a transitional justice process is necessary for the future, in reality, there is often little energy left when the spotlights in the criminal justice courtroom have been turned off, and the wise recommendations of the truth and reconciliation are noted, but never implemented and even less enforced. If one remembers that the full application of human rights and international criminal law cannot replace a democratic and inclusive political process, these fields of law can help enable such a development. ${ }^{5}$

Nonetheless, even if international law could be better used, there are limits to what can be accomplished even with creative international law expertise. There is a structural bias in international law, namely, its privileging of the state.

As alleged by critics such as Adam Branch, international law, as practised by some agencies and organisations, takes the situation out of the control of the people concerned, and may thus contradict democracy. The real problem is not that there is an intervention because it is usually the government's unwillingness to grant such rights and to treat the people concerned as autonomous agents, which legitimises the international intervention. The problem is that international law, and its institutions, can do too little to refer the matter from the government to other legitimate stakeholders, often leaving us with a choice between the (distant) supranational level and the (corrupt) national level.

For sure, international law is increasingly penetrating relations between the state and individuals (human rights), and increasingly often also relations between private subjects (international criminal law). There is increasing talk of "subsidiarity" in human rights monitoring and "complementarity" in international criminal law. Nevertheless, these doctrines refer back to the state-level. If the state is corrupt, or if the decision in question ought to be referred to subsidiary or transnational bodies - because political communities are formed in overlapping, concentric and non-concentric circles -- then international law has no clear provisions. Public services and protection of the private sphere can be supplied not only by the state but also by other collective bodies. And there are many more spaces and more levels that could usefully be involved. Yet, none of these subnational or transnational formal levels and spaces has been discussed much in terms of the administration of human rights and transitional justice.

Those most affected by the war in northern Uganda were certainly victims of crimes, and that is how they were treated by those who provided humanitarian assistance or advocated human rights. The victims had easily identifiable claims supported by international law (although often unsatisfied). However, even the people in the IDP camps were more than just victims, or objects of "protection" of various agencies. They were also participants in local community-based organisations (CBOs), members of clans and tribes and voters in national and local elections. In

\footnotetext{
${ }^{5}$ Several provisions of the Juba Agreement on Comprehensive Solutions did address the political process, but in the absence of political will and external pressure, not much was implemented.
} 
these different capacities they had different interests and different claims, but this was much harder to formulate in terms of international law. It is difficult to say, with any precision, how the international legal rights of indigenous peoples or the right to take part in public affairs shall be implemented in the design of a truth and reconciliation commission. And there are few examples of international institutions that give non-state stakeholders a place at the negotiating table. Therefore, under international criminal law regimes, and most (if not all) other international regimes, it is still a choice between allocating jurisdiction to international professionals and diplomats, or to leave it to the government, despotic or not. While international law does determine an international minimum standard for the state, it is still much better at empowering the government than at empowering people.

\section{Intervention, Reflection}

I have been an international lawyer for 25 years, including 15 years in practise. As an international lawyer, it is easy to take it for granted that you are acting for the good, and in fact, this is a part of your professional identity. However, as Martti Koskenniemi writes in the final chapter of From Apology to Utopia, the international lawyer is caught between the identity of a Grotian cosmopolite and that of a national bureaucrat, or, in more generic terms, between her commitment to a higher good and her role as a professional on mission. Professional choices choices of profession as well as choices in the profession - are also ethical choices. Who you choose to work for and what you accept to do in your work are decisions that entail responsibility.

I have become increasingly sceptical of the proposition that international law is good as such. For sure, international law is much better than war and genocide. However, the decision facing an international lawyer in a political crisis is usually not to decide whether to initiate a genocide or not (lawyers are not necessary to answer this question), but how to prevent or stop a genocide or how to reconcile a society after a conflict. For such questions, international law will not provide the whole answer, or even a good one. I have discussed some of the biases, which are inherent in international legal discourse, and these biases are sometimes useful (power arguments are not acceptable) and sometimes less useful (social justice and power-sharing are difficult to assess under international law).

So what do you do as an international lawyer? Sometimes it is better to retreat into the role of a law expert and leave considerations of justice or the assessment of various social facts to others; and sometimes it is wiser to step out of your role as a technician and engage in ethics and politics, beyond the confines of international law. When to do one or the other depends on the set-up of the deliberations, the relations between the parties, the issues involved, your role and what you can bring to the table. There are no formulas, and ultimately the decision can only be determined by judgment and experience. What one can always ask for, though, is a reflective, critical and self-critical approach; an approach that is critical of your role, of the role of international law as well as of the institutions that you represent and the values that you symbolise; an approach that enables you to appreciate both the values and the limitations of international law. 